\title{
An Evaluation of the Effect of Agricultural Extension Delivery on Resource-Poor Farmers' Income from Yam in Cross River State, Nigeria.
}

\author{
Agbarevo, Machiadikwe N. Benjamin' Department of Agricultural Education, Federal \\ College of Education, Obudu, Cross-River State, Nigeria.
}

\begin{abstract}
Agricultural extension is designed to increase farmers' productivity and well-being through the adoption of improved agricultural extension technological recommendations. Against this background, the study was conducted to determine the effect of adoption of agricultural extension recommendations on the resourcepoor farmers' income from yam. In conducting the study, 180 yam farmers from Cross River State were randomly selected through multi-stage stratified random sampling technique. The data collected were analyzed using linear correlation and regression analysis at 5\% level. The study showed that agricultural extension through farmers' adoption of technological recommendations significantly increased farmers' income from yam. The null hypothesis that agricultural extension does not increase farmers' income from yam significantly was rejected, while the alternative hypothesis was accepted.
\end{abstract}

Keywords: Evaluation, Effect, Extension-Delivery, Resource-poor, income, farmers, Yam.

\section{Introduction}

Yam is a major staple food in Nigeria and, indeed, Africa. Nigeria is, however, the world's largest producer of yams, producing 27 million metric tones per annum (Nwosu, 2005). Considering the importance of yam as a staple food and the income derivable from it, efforts aimed at improving its production should be optimized.

Poor adoption rate of extension recommendations has been seen as being responsible for poor agricultural production. It is believed that with higher rates of adoption of recommendations by resource poorfarmers, crop yields would increase. In this regard, Omagbemi (1998) observed that adoption of technological innovations by resource-poor farmers would lead to increased farm yields. In the same vein, Swanson et al. (1984) noted that adoption of recommended extension technologies contributes to increase food production (yield). This increase in yield translates into increased farmers' income.

Nwosu (2005), Bakare et al. (2004), Ehirim et al. (2005), and Eke-Okoro (2006) posited that a positive correlation exists between adoption of improved crop technologies and yield. They concluded that the poor yield of crops was as a result of poor adoption of extension recommendations, and that crop yields could be increased by getting farmers to more readily adopt improved crop production technologies packaged by extension and research. Therefore, improvement in agricultural extension delivery would lead to increased adoption of agricultural extension recommendations, which in turn leads to increased yield of yam. The increase in yam yield would consequently lead to increased income from yam. This means that Nigeria, still has great potentials to increase her current level of yam production and the derivable income through improved extension delivery. In this regard Kaine (2004) observed that adoption of extension recommendations by farmers leads to increase in crop yields, which in turn impacted substantially on the farmers' income and in many instances their lifestyle.

\section{Study Area Descriptions}

Cross River State, which is the area of study, is in the South- South geo-political zone of Nigeria. It is bounded to the south by the Atlantic ocean, to the east by the Republic of Cameroon, to the south-west by Akwa-Ibom State, to the west by Abia and Ebonyi States, and to the north by Benue State. It lies between the co-ordinates of latitudes $6 \square \mathrm{N}$ and $8 \square \mathrm{E}$ of the Equator. There are three main cities in the state: Calabar (the state capital) in the south, Ikom in the central zone and Ogoja in the northern zone. The inhabitants of the state are mainly farmers. Most of the local governments have several rivers, which encourage fishing activities. The farmers are mainly resource-poor. Farmers in the south and central zones are predominantly arable crop farmers. Crops produced include maize, yam, cassava, plantain, banana, cocoa yam, etc. However, Ikom in the central zone is noted for production of cocoa in addition to the other crops. Boki Local Government, which is also in the central zone is noted for the production of cocoa and palm oil in commercial quantities. Farmers in the north produce cassava, yam and maize but to a less extent. They, however, produce rice and groundnuts in greater quantities than the other zones. Generally, cassava, yam and maize are the major crops grown in the state. 
The state has a population of about 3million and a land mass of 22156 square kilometers with wide expanse of arable lands, which encourage arable and plantation farming. As typical of areas in Nigeria with many rivers, the state has a multiplicity of languages with more than one language spoken in some local governments. Cross River State is adapted to the production of a wide range of crops because of variation in the soil and climatic conditions. The south of Cross River and its environs are essentially mangrove forest, swamp and tropical rainforest. Cross River central is essentially a rainforest belt, while Cross River North is essentially guinea savanna belt.

\section{Materials And Methods}

In conducting the study, 180 Agricultural Development Project (ADP) yam farmers were randomly selected through multi-stage stratified sampling technique. The state was divided into three Agricultural Development Project (ADP) zones. Three blocks were selected from each zone and two cells from each of the nine blocks selected, giving a total of eighteen cells. Ten farmers were randomly selected from each cell, giving a sample size of 180 farmers.

The data used for the study were collected with the use of a structured questionnaire. The researcher was assisted in the distribution and collection of the questionnaire by the Agricultural Development Project staff and enumerators. The data on adoption of extension recommendations and income were collected and analyzed using linear correlation and regression analysis. To obtain an adoption index for each farmer, farmers' responses were categorized into: (a) rarely adopted (b) adopted and stopped and (c) adopted and still using innovation, to which numerical values 1, 2 and 3 were assigned respectively. The mean response was computed and used as the adoption index. The null hypothesis that adoption of agricultural extension recommendations for yam production does not influence yam income significantly was tested at $95 \%$ confidence level using linear correlation and regression analysis.

The regression equation is given by the formula: ' $y=a+b x$ '

Where:

$\mathrm{y}=$ income (dependent variable).

$\mathrm{a}=$ intercept

$\mathrm{b}=$ slope

$\mathrm{x}=$ adoption (independent variable)

Table 1: The effect of Adoption of Agricultural Extension Recommendations for Yam Production on Farmers' Yam Income

\begin{tabular}{lccr}
\hline Variable & $\begin{array}{c}\text { (B) } \\
\text { Coefficients }\end{array}$ & $\begin{array}{c}\text { Standard } \\
\text { Error }\end{array}$ & t-value \\
Constant & -11321.770 & 9411.114 & -1.203 \\
Adoption & 10765.343 & 4516.401 & 2.384 \\
R & 0.17587 & & \\
R-Square & 0.03093 & & \\
F-Value & $5.68160^{*}$ & & \\
Sample size & 180.00 & & \\
\hline
\end{tabular}

*Significant at 5\% Ho: Reject

IV. Results And Discussion

Table 1 shows the estimated linear regression analysis - the effect of adoption of agricultural extension recommendations on yam production on farmers' yam income. The analysis as shown in table 1 indicates that a unit increase in the level adoption would increase farm income from yam by ten thousand seven hundred and sixty-five naira $(\mathrm{N} 10,765)$. The coefficient of determination $\left(\mathrm{R}^{2}\right)$ of 0.03 with F-value of 5.7 is significant at $5 \%$ level. Therefore, the null hypothesis that adoption of agricultural extension recommendations for yam production has no significant effect on farmers' yam income was rejected, while the alternative hypothesis was accepted.

Farmers' derive income from the sale of their products. Therefore, increase in farmers' income is dependent upon increase in output. Increase in yield would, therefore, invariably lead to increase in the farmers' income. In this regard Omagbemi (1988) observed that adoption of technological innovations by resource-poor farmers would lead to increase in farm yield. Swanson et al. (1984) equally found that adoption of recommended extension technologies contributes to increased food production (yield). This increase in yield translates to increase in farmers' income.

Nwosu (2005), Bakare et al. (2004), Ehirim et al. (2005) and Eke-Okoro (2006) in support of the finding of this study, equally reported a positive correlation between adoption of improved crop production 
technologies and yield. They concluded that the poor yield of crops was as a result of poor adoption of extension recommendations, and that crop yields could be increased by getting farmers to more readily adopt improved crop production technologies packaged by extension and research. Therefore, improvement in agricultural extension delivery would lead to increase in adoption of agricultural extension recommendations, which in turn leads to increased yield of yam.

The increase in yam yield would consequently lead to increased income from yam. This means that Nigeria still has great potentials to increase her current level of yam production and the derivable income through improved extension delivery. In this regard Kaine (2004) observed that adoption of extension recommendations by farmers leads to increase in crop yields, which in turn impacted substantially on the farmers' income and in many instances their lifestyle. This would equally increase the nation's Gross Domestic Product (GDP). Similarly, Emeson (2006) and Farm and Infrastructural Foundation (2007) reported positive correlation between adoption of extension recommendations by farmers and crop yields. Improvement in the quality of extension delivery would, therefore, increase adoption of yam production technologies and, consequently, the yield of yam.

The study has shown that improvement in agricultural extension delivery would lead to increased adoption of agricultural extension recommendations for yam production by resource-poor yam farmers. This would in turn lead to increased yield of yam and consequently, increase in the farmers' income. This calls for concerted efforts to improve agricultural extension delivery system for improved adoption and yield. It has been observed (Agbarevo, 2007) that agricultural extension would be more effective under the contextual framework of group extension, participation and farming systems research. This would enable Nigeria to optimize its production potentials in yam and the concomitant increase in farmers' income and their general well-being.

\section{References}

[1] Agbarevo, M. N., 2007. Enhancing adoptions of agricultural extension technological packages within the contextual framework of participation, group extension and farming systems research. Journal of Research in Agriculture 4 (4) 1-6.

[2] Bakare, S. O., Ukwungwu, M. N., Fademi, A. O., Harris, D and Ochigbo, A. (2004). Adoption study of seed priming technology in upland rice in O. O. Agbede, M. B. Idris, S. A. Rahman, M..M. Ari, I. M. Ogara and G. N. Asumugha,( eds.). Mobilizing Investors for Sustainable Agricultural Research Development and Production in Nigeria -Proceedings of the $28^{\text {th }}$ Agric Society of Nigeria. Held at the College of Agric. Nasarawa State. October 17-21, 2004.

[3] Ehirim, N. C., 2005. Economic impact of common agronomic practices associated with risk control in cassava production in Owerri., in A. M. Orheruata et al. (eds.). Agricultural Rebirth for Improved Production in Nigeria. Proceedings of $39^{\text {th }}$ Annual Conference of the Agricultural Society of Nigeria. Held at University of Benin, Benin City, October $9^{\text {th }}-13^{\text {th }} 2005$.

[4] Eke-Okoro, C. N., 2004. Optimum rate of new compound fertilizer for cassava production in south eastern Nigeria. Journal of Research in Agriculture 4 (1): 23-26.

[5] Emeson, R. A and Nwabu, G., 2006. Effects of agricultural extension on farm yields in Kenya. Center Discussion Paper, No 798. Yale University Economic Growth Center, New Haven Connecticut.

[6] Farm and Infrastructural Foundation, 2007. New Agric. Digest. FIF Press, Abuja.

[7] Kaine, G., 2004. Consumer behavior as a theory of innovation adoption in agriculture. Understanding Adoption of Precision Agriculture Technologies. APEN International Conference.

[8] Nwosu, C. S., 2005. Comparative economics of resource use by ADP and non-ADP contact farmers in Orlu Agricultural Zone of Imo State, Nigeria in A. M. Orheruata et al. (eds). Agricultural Rebirth for Improved production in Nigeria. Proceedings of the $39^{\text {th }}$ Annual Conference of the Agricultural Society of Nigeria. Held at the University of Benin City, Nigeria. October, 2005. 